\title{
Impact of high penetration of wind and solar PV generation on the country power system load: The case study of Croatia
}

\author{
Ivan Komušanac ${ }^{a}$, Boris Ćosić ${ }^{b, *}$, Neven Duića $^{a}$ \\ ${ }^{a}$ University of Zagreb, Faculty of Mechanical Engineering and Naval Architecture, Zagreb, Croatia \\ ${ }^{\mathrm{b}}$ Adria Section of the Combustion Institute, Zagreb, Croatia
}

\section{H I G H L I G H T S}

- 69 scenarios of wind and solar PV as a base technology are analysed with EnergyPLAN model.

- Pareto analysis is used for selection of the optimal scenario.

- Multi-criteria analysis was performed in order to observe the behaviour of grading the scenarios.

- Results shows optimal mix of $1.65 \mathrm{GW}$ of wind and $1.6 \mathrm{GW}$ of solar PV.

\section{A R T I C L E I N F O}

\section{Article history:}

Received 27 November 2015

Received in revised form 16 May 2016

Accepted 18 June 2016

Available online 4 July 2016

\section{Keywords:}

EnergyPLAN

Wind power plants

Solar PV

Multicriteria-analysis

Pareto analysis

\begin{abstract}
A B S T R A C T
Even though the Republic of Croatia is on track of achieving goals set in the Europe 2020 strategy, to achieve the goals set in the 2030 European framework for climate and energy policies will require more effort. The new 2030 framework calls for a reduction in greenhouse gas emissions by at least 40\% compared to the 1990 level, yet the Republic of Croatia does not have such an ambitious plan. In times when wind plants and photovoltaic systems have reached grid parity in the majority of European countries, this paper analysed the influence of construction of wind and photovoltaic power plants in order to present the optimal constructing ratio of such systems on the Croatian power system load. Simulations have been conducted in the EnergyPLAN model for the year 2012. After the simulation presented promising scenarios, applying the Pareto analysis showed the optimal scenario for generating electricity from renewables, scenario with the lowest import of electricity, scenario with the lowest $\mathrm{CO}_{2}$ emissions and with the lowest critical excess electricity production. In addition, all of the scenarios were subjected to a multiple criteria decision analysis in order to find the best overall scenario. After showing that the best overall scenario was $1.65 \mathrm{GW}$ of wind power plants and $1.6 \mathrm{GW}$ of installed PV capacity, a multi-criteria analysis was performed in order to observe the behaviour of grading the scenarios. Indeed, all of the simulations proved that PV will have a bigger role in the Republic of Croatia than expected.
\end{abstract}

(c) 2016 Elsevier Ltd. All rights reserved.

\section{Introduction}

In 2012, the primary energy import dependency of the EU-27 reached a level of $53.4 \%$ and an increase of $20 \%$ since 1995 , with predictions of reaching $70 \%$ in the next $20-30$ years [1]. In order of achieving an independent energy system, as well as reducing $\mathrm{CO}_{2}$ emissions, the European Union has set new goals for the year 2030 and 2050 . The goals include a $27 \%$ of gross energy consumption from renewable energy sources (RES) until 2030 [2] and 95\% reduction of $\mathrm{CO}_{2}$ emissions from the energy sector until 2050 [3].

\footnotetext{
* Corresponding author at: Ivana Lučića 5, 10000 Zagreb, Croatia.

E-mail addresses: ivan.komusanac@stud.fsb.hr (I. Komušanac), Boris.Cosic@fsb. hr (B. Cosić), Neven.Duic@fsb.hr (N. Duić).
}

In order to reduce carbon footprint, several different ways of approach have been studied by various authors. In over $40 \%$ of all EnergyPLAN related articles, authors used the EnergyPLAN tool for analysis of the $\mathrm{CO}_{2}$ emissions reduction [4]. While several papers focus on a specific country approach for $\mathrm{CO}_{2}$ reduction [5], a significant share of them was focused on small regions such as islands [6] and cities [7] which are considered as the worst cases for achievement of a 100\% RES system, or even on specific sectors such as energy [8], transport [9], residential [10], households [11] which are the highest consumers of energy and at the same time sectors with the highest potential for $\mathrm{CO}_{2}$ emission reduction and high share RES integration. In addition, several authors analysed the integration of wind power with electric vehicles [12], while others used electric vehicles as a storage option for all energy 
sources [13]. Furthermore, some authors wrote papers where they were going a step further by exploring scenarios in which would be possible to achieve a $100 \%$ RES system. Such papers have been already made for Croatia [14], and other European countries. From all the mentioned papers, the conclusion was that for a successful planning of an energy system, scenario approach and long-term energy demand assessment that has to be met by the system [15] are the most important. Because of this the implementation of RES has become a very important factor after the RE-thinking 2050 [3].

In addition, RE-thinking 2050 calls for phasing out fossil fuels, but only some of the EU countries, like Denmark, have already redefined their energy strategies aiming on a high share of RES and reaching a $100 \%$ RES system in a near future [16], most of the member countries did not yet update their energy strategies to follow the goals set by the 2050 European framework. However, energy strategies for some countries such as Germany [17] and Ireland [18] have already put emphases on a high penetration of RES energy in existing strategies. Significant implementation of RES has already begun - 2012 was a significant year for renewable power plants, from a capacity-wise standpoint. An amount of $11.9 \mathrm{GW}$ of new wind power plant has been installed in the EU, accounting for $26.5 \%$ of total power capacity installation and in the last two years, wind power recorded an annual growth rate of over $11.6 \%$ [19]. Such promising numbers are the reason that there was already a paper on Croatia's energy system planning with a large penetration of wind energy [20]. On the other hand, solar energy had a boom with $38.7 \mathrm{GW}$ installed globally in 2014, PV capacity has reached $177 \mathrm{GW}$ worldwide [21]. In addition, the Croatian Energy Strategy predicts phase-out of all present thermal power plants that use fuel oil and coal, until 2030 [22] which provides additional space for a high share of RES integration.

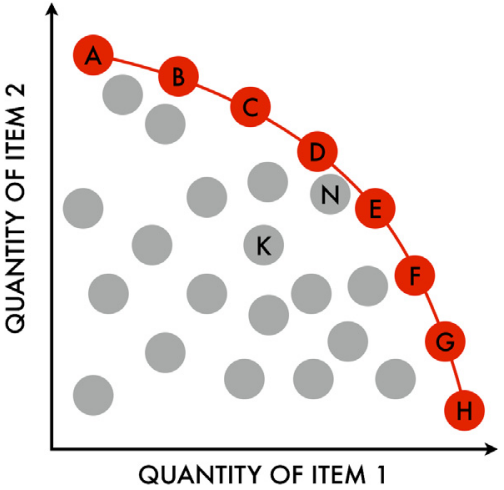

Fig. 2. Schematic model of the Pareto front [38].

A high share integration of RES, such as wind and PV, is often considered limited due to the intermittent nature of these sources and at the same time due to the limitations set by electricity demand of the region, island or country which are not so flexible and cannot be easily changed. Because of this many papers were focused on analysis of the optimal portfolio of these sources such as in the case of Brazilian energy system [23], the future energy system of China [24] or in the case of fully renewable US electricity energy system [25]. Also, the influence of a high penetration of wind and PV installation on power system frequency response was analysed in [26], while in [27] the authors analysed influence of the mitigation strategies on change in the marginal economic value of combined wind and PV technologies at various penetration levels in California. The main conclusion from these studies

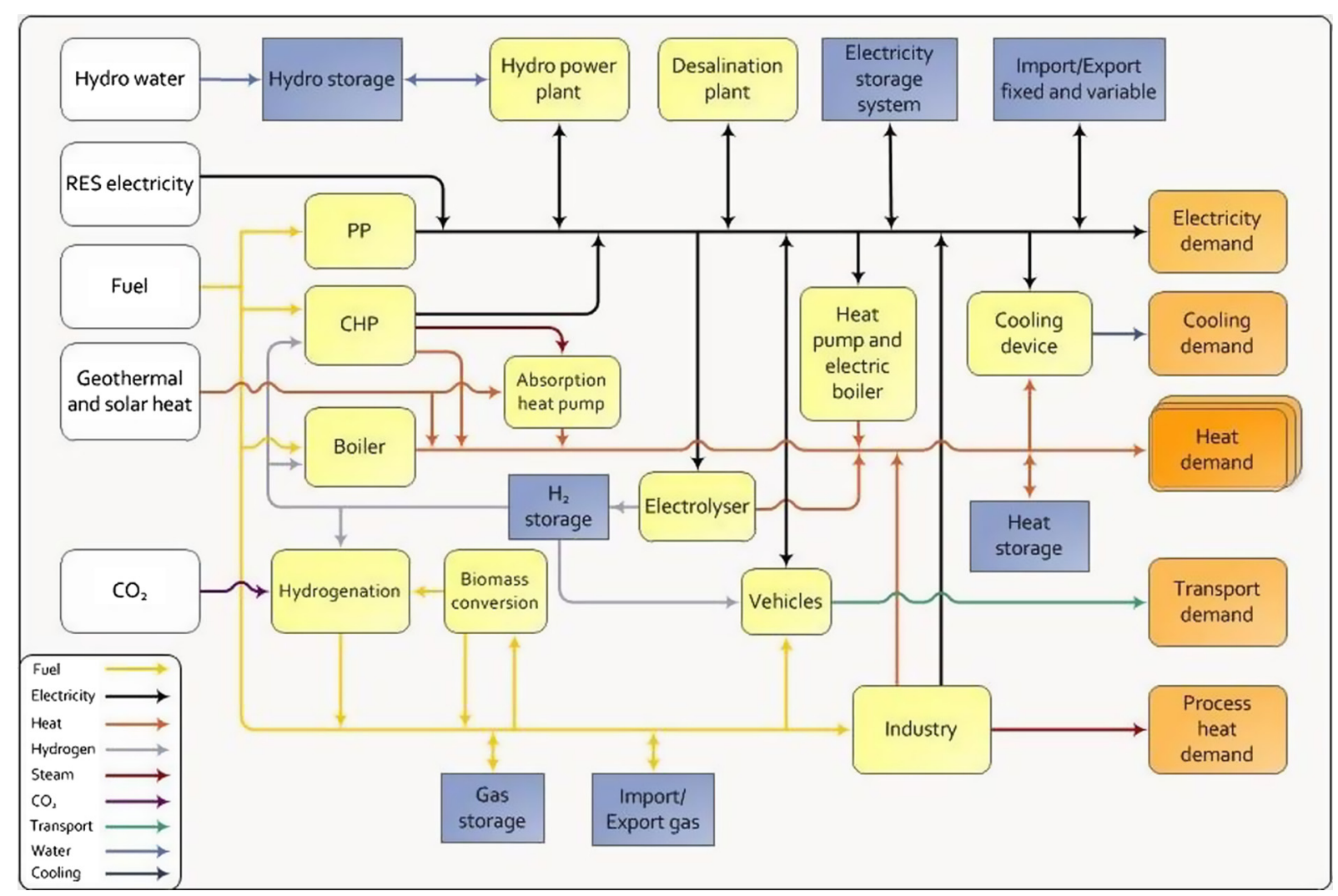

Fig. 1. Schematic model of the EnergyPLAN tool. 


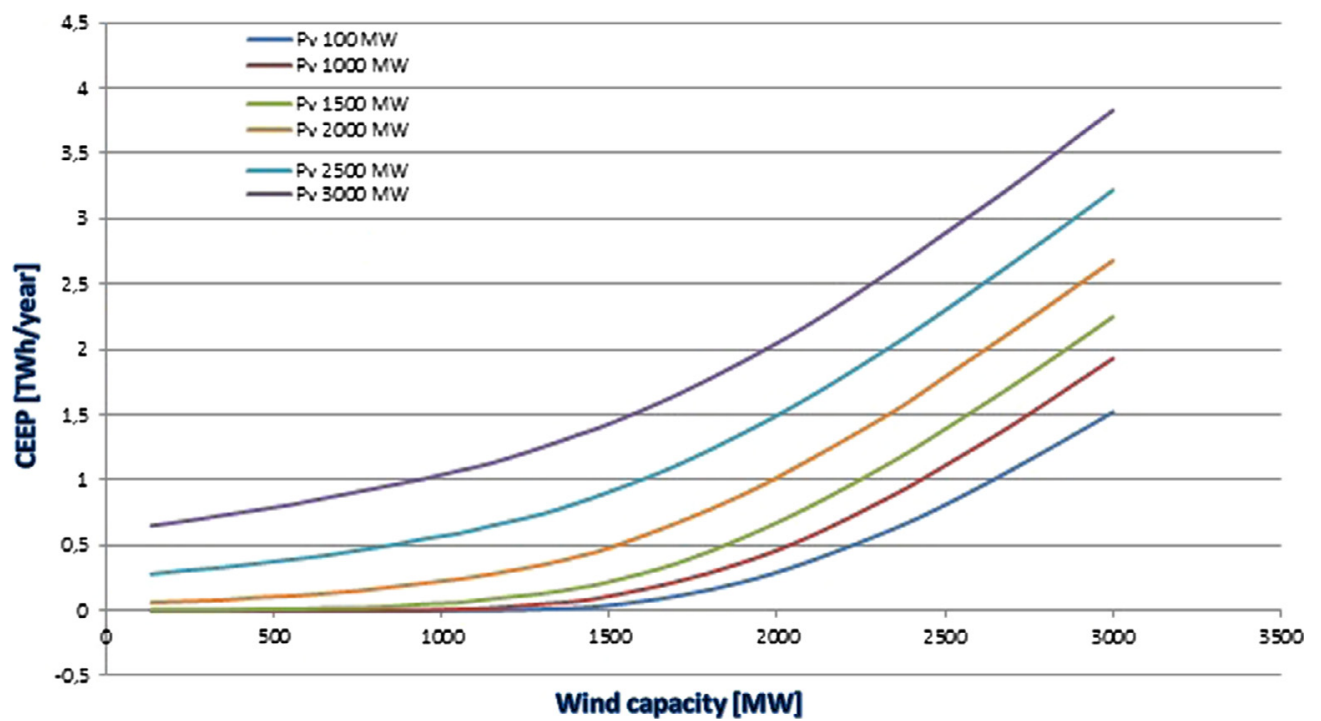

Fig. 3. Growth of CEEP with increase in installed wind capacity.

was that with the optimal mix of wind and PV technologies, significant savings could be achieved in terms of storage size, backup energy and $\mathrm{CO}_{2}$ emissions compared to a high share installation of individual RES technology.

The purpose of this paper is to present a scenario for the Croatia's energy strategy which would have the highest impact on the reduction of both the $\mathrm{CO}_{2}$ emissions and import of the electricity and at the same time the lowest critical excess electricity production (CEEP). Furthermore, analysis conducted in this paper showed that the energy system of Croatia could take up more renewable energy and be almost independent at the same time compared to the current situations and numbers stated in the National action plan for renewables. First, a reference model for the year 2012 which corresponds to the data from IEA was created. After creating the reference model, an analysis which showed how the capacity of wind power plants and PV systems impact on critical excess electricity production (CEEP), electricity import, $\mathrm{CO}_{2}$ emissions and the amount of electricity generated from renewable energy was conducted. That analysis was followed by a Pareto analysis of those systems which allowed reducing hundreds of scenarios to a few dozen. All of those scenarios were optimal scenarios in their respective fields, according to the Pareto analysis. However, the resulting scenarios after the Pareto analysis were subjected to a multi-criteria analysis and the best overall scenario will be presented.

\section{Methodology}

For analyses and comparison of various proposed scenarios, the EnergyPLAN freeware model [28], developed at the Aalborg University in Denmark, was used (Fig. 1). The EnergyPLAN model is input output model which optimises on hourly basis and consists of several sectors such as electricity production, heating and cooling, industry, transport, storage and water [29]. The EnergyPLAN tool is used to model islands, cities, regions, and countries energy

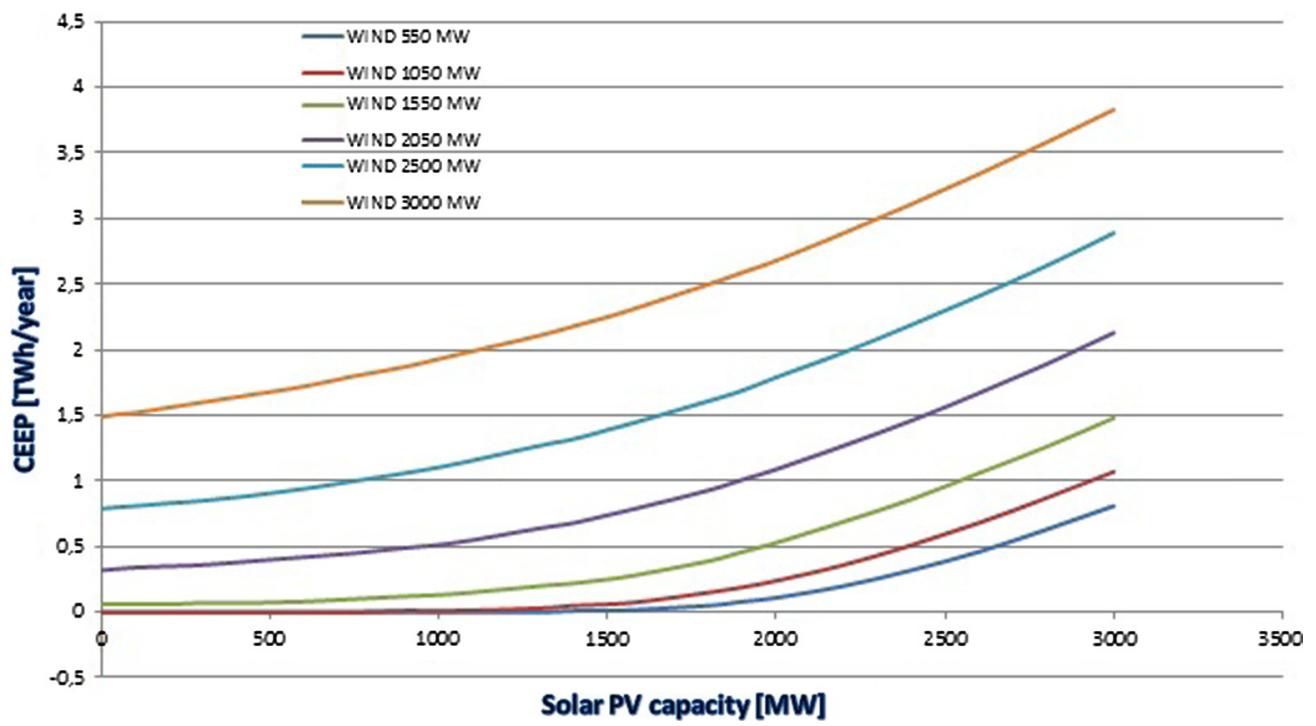

Fig. 4. Growth of CEEP with increase in installed PV capacity. 


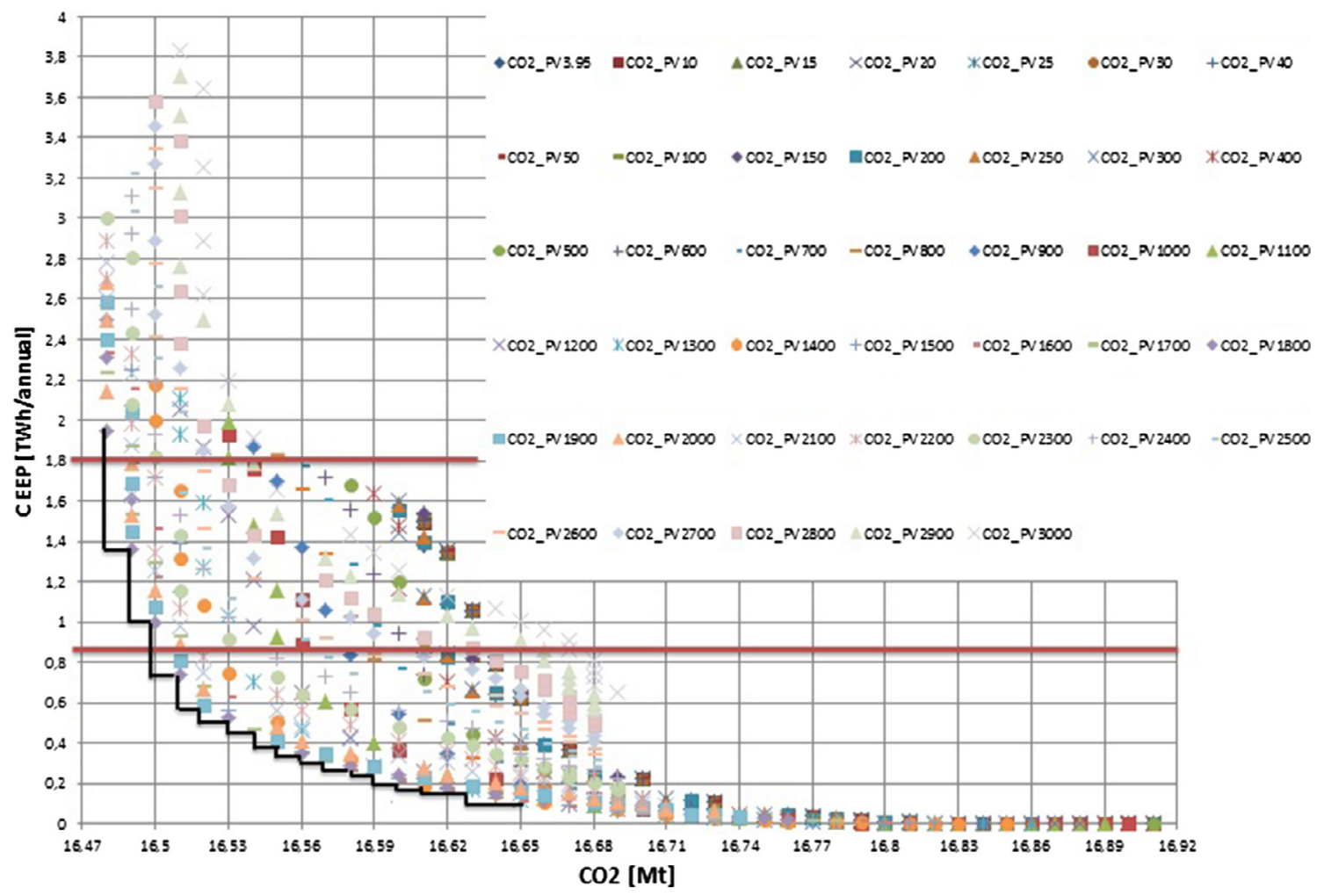

Fig. 5. Pareto analysis of scenarios in case when PV is base technology.

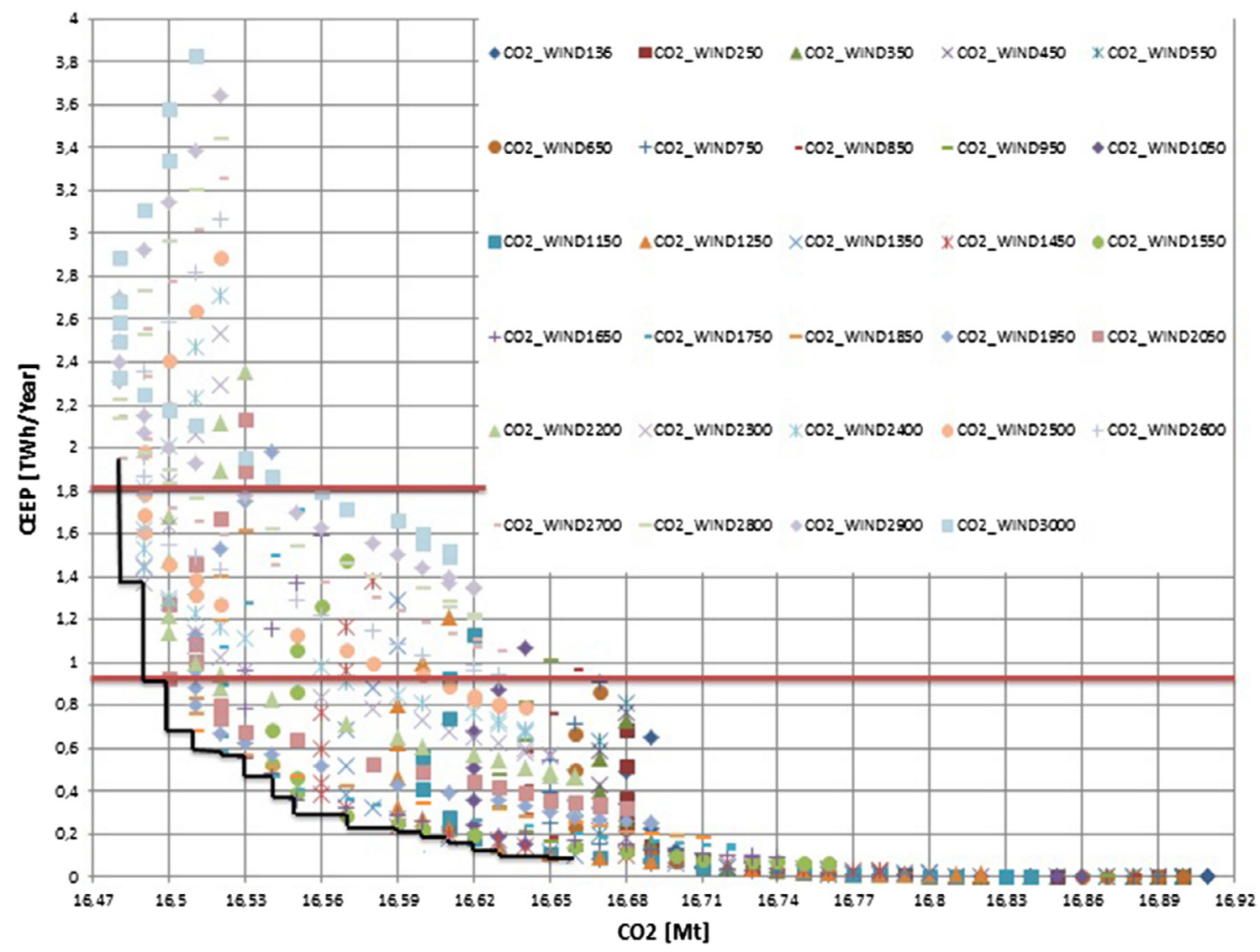

Fig. 6. Pareto analysis of scenarios in case when the wind is base technology. 
Table 1

Optimal scenarios for the CEEP- $\mathrm{CO}_{2}$ chart when the PV capacity is constant.

\begin{tabular}{llllll}
\hline $\begin{array}{l}\text { Wind } \\
\text { capacity } \\
{[\mathrm{MW}]}\end{array}$ & $\begin{array}{l}\text { PV capacity } \\
{[\mathrm{MW}]}\end{array}$ & $\begin{array}{l}\mathrm{CEEP} \\
\text { [TWh/ } \\
\text { year] }\end{array}$ & $\begin{array}{l}\text { Import } \\
\text { [TWh/year] }\end{array}$ & $\begin{array}{l}\mathrm{RES} \\
{[\mathrm{TWh} /} \\
\text { year] }\end{array}$ & $\begin{array}{l}\mathrm{CO}_{2} \\
\text { emission } \\
{[\mathrm{Mt}]}\end{array}$ \\
\hline 2350 & 1800 & 1.36 & 1.36 & 12.96 & 16.49 \\
2100 & 1800 & 1 & 2.21 & 12.36 & 16.5 \\
1900 & 1800 & 0.74 & 2.4 & 11.89 & 16.51 \\
1700 & 1900 & 0.59 & 2.55 & 11.55 & 16.52 \\
1700 & 1800 & 0.53 & 2.62 & 11.41 & 16.53 \\
1700 & 1700 & 0.46 & 2.68 & 11.27 & 16.54 \\
1500 & 1900 & 0.41 & 2.79 & 11.08 & 16.55 \\
1500 & 1800 & 0.35 & 2.85 & 10.93 & 16.56 \\
\hline
\end{tabular}

Table 2

Optimal scenarios for the CEEP- $\mathrm{CO}_{2}$ chart when the wind capacity is constant.

\begin{tabular}{|c|c|c|c|c|c|}
\hline $\begin{array}{l}\text { Wind } \\
\text { capacity } \\
\text { [MW] }\end{array}$ & $\begin{array}{l}\text { PV capacity } \\
{[\mathrm{MW}]}\end{array}$ & $\begin{array}{l}\text { CEEP } \\
\text { [TWh/ } \\
\text { year] }\end{array}$ & $\begin{array}{l}\text { Import } \\
\text { [TWh/year] }\end{array}$ & $\begin{array}{l}\text { RES } \\
\text { [TWh/ } \\
\text { year] }\end{array}$ & $\begin{array}{l}\mathrm{CO}_{2} \\
\text { emission } \\
{[\mathrm{Mt}]}\end{array}$ \\
\hline 2300 & 1900 & 1.37 & 1.99 & 12.98 & 16.49 \\
\hline 2050 & 1050 & 0.53 & 2.8 & 11.8 & 16.58 \\
\hline 1850 & 1800 & 0.68 & 2.46 & 11.77 & 16.51 \\
\hline 1750 & 1900 & 0.58 & 2.56 & 11.53 & 16.52 \\
\hline 1650 & 1900 & 0.55 & 2.61 & 11.43 & 16.53 \\
\hline 1750 & 1600 & 0.46 & 2.69 & 11.24 & 16.54 \\
\hline 1650 & 1600 & 0.36 & 2.81 & 11.01 & 16.55 \\
\hline
\end{tabular}

systems as well as for the analysis of a high share penetration of intermittent renewable energy sources in national and regional energy systems [30]. The EnergyPLAN model is used for the analysis of $100 \%$ renewable energy systems of Denmark [31], Ireland [32], Macedonia [33] and Mexico [34] and for the analysis of the influence of a high share of intermittent renewable energy sources on the energy systems of China [35] and the UK [36]. The EnergyPLAN model works on an hourly basis.

The inputs consist of a power plant's capacity, production and distribution, electricity and heat demand, fuel consumption, biofuels production and storage capacities. The outputs include energy balance in the primary energy supply, share of renewable energy sources, electricity production from conventional and RES technologies, emissions, import and export of electricity and CEEP. EnergyPLAN offers the user a choice between a technical and a market optimisation regulation. The technical regulation strategies try to minimise the import and export of electricity and fuel consumption, while the market regulation seeks to optimise plant operation based on marginal production costs. After choosing the technical optimisation, the user can choose between: balancing heat demand or balancing both electricity and heat demand. In this paper, the technical optimisation with balancing both heat and electricity demand was chosen in order to minimise the critical excess electricity production (CEEP). CEEP is the amount of excess electricity produced that could not be used in the energy system or exported and it can lead to frequency changes and grid collapse. The usage of the EnergyPLAN model is increasing with every year. Therefore, it was applied in 95 different peer reviewed journal articles, while the results have been referred in 45 other articles. In addition, the model was characterised in 40 articles as of May 26th 2015 [4]. Detailed information about behaviour and technology preferences for both regulation options are explained in the model's manual [37].

\section{Energy scenarios}

Due to its specific mode, EnergyPLAN itself cannot optimise the values of both the PV and wind power while showing the results, therefore, one of the variable energy sources has to have the input as a constant value. For instance, if the amount of installed wind power capacity is changing from $100 \mathrm{MW}$ to $3 \mathrm{GW}$ it can only be carried out in the EnergyPLAN tool if the other energy sources (in this case solar PV) are constant. Because of that, two major scenarios were developed in this paper, one with a constant number of installed wind power plants and a second one, with a constant amount of installed PV capacity. In the case when the wind is acting as the base technology, installed wind capacity was increased from $136 \mathrm{MW}$ to $2050 \mathrm{MW}$ and then from $2200 \mathrm{MW}$ to $3000 \mathrm{MW}$ with a step of $100 \mathrm{MW}$, in total creating 29 wind base scenarios. In the case when the solar PV is acting as the base technology, installed PV capacity was increased from $3.95 \mathrm{MW}$ to $30 \mathrm{MW}$ with a step of $5 \mathrm{MW}$, from $30 \mathrm{MW}$ to $50 \mathrm{MW}$ with a step of $10 \mathrm{MW}$, from $50 \mathrm{MW}$ to $300 \mathrm{MW}$ with a step of $50 \mathrm{MW}$ and from $300 \mathrm{MW}$ to $3000 \mathrm{MW}$ with a step of $100 \mathrm{MW}$, in total creating 40 scenarios with the PV as the base technology. Furthermore, each of these base scenarios had additional 22 scenarios developed for different installed capacities of wind in the case when the PV is acting as the

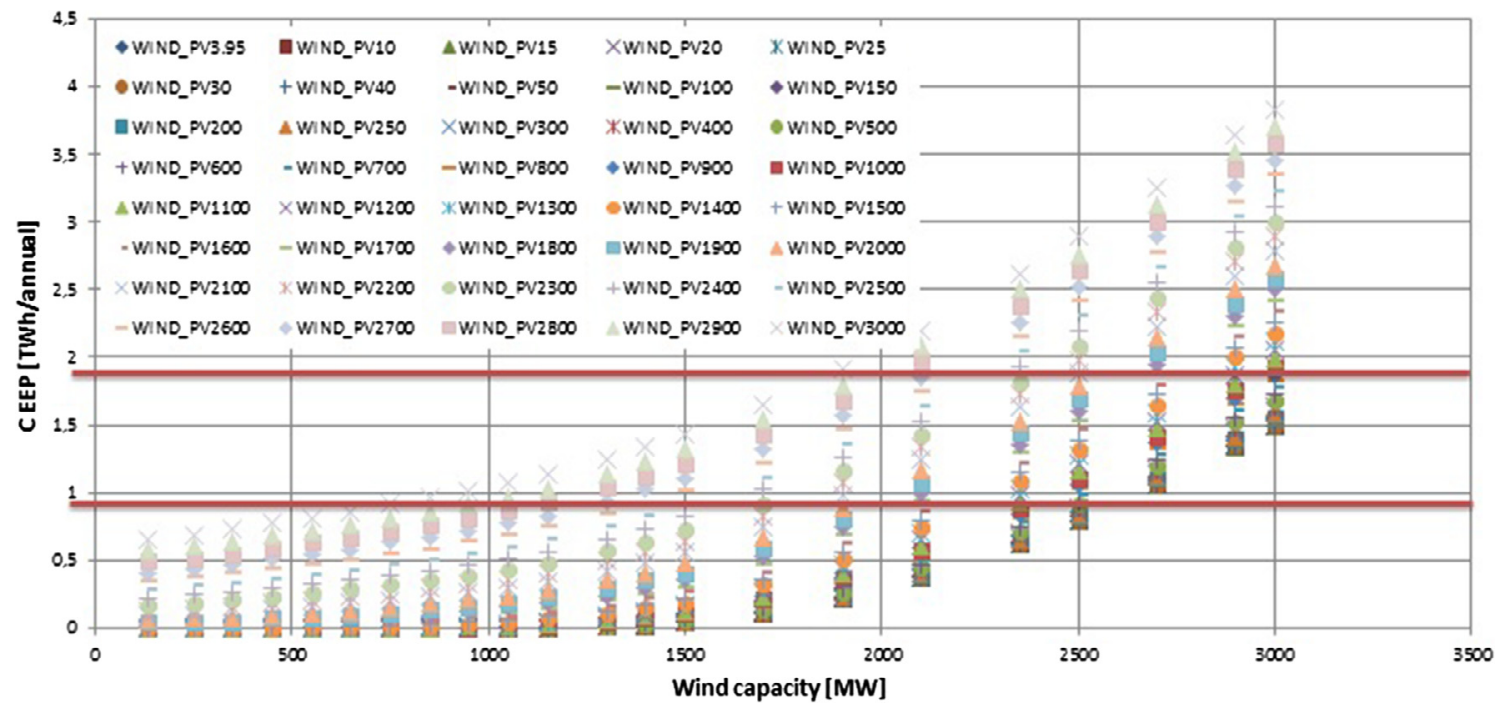

Fig. 7. CEEP-Wind capacity chart. 


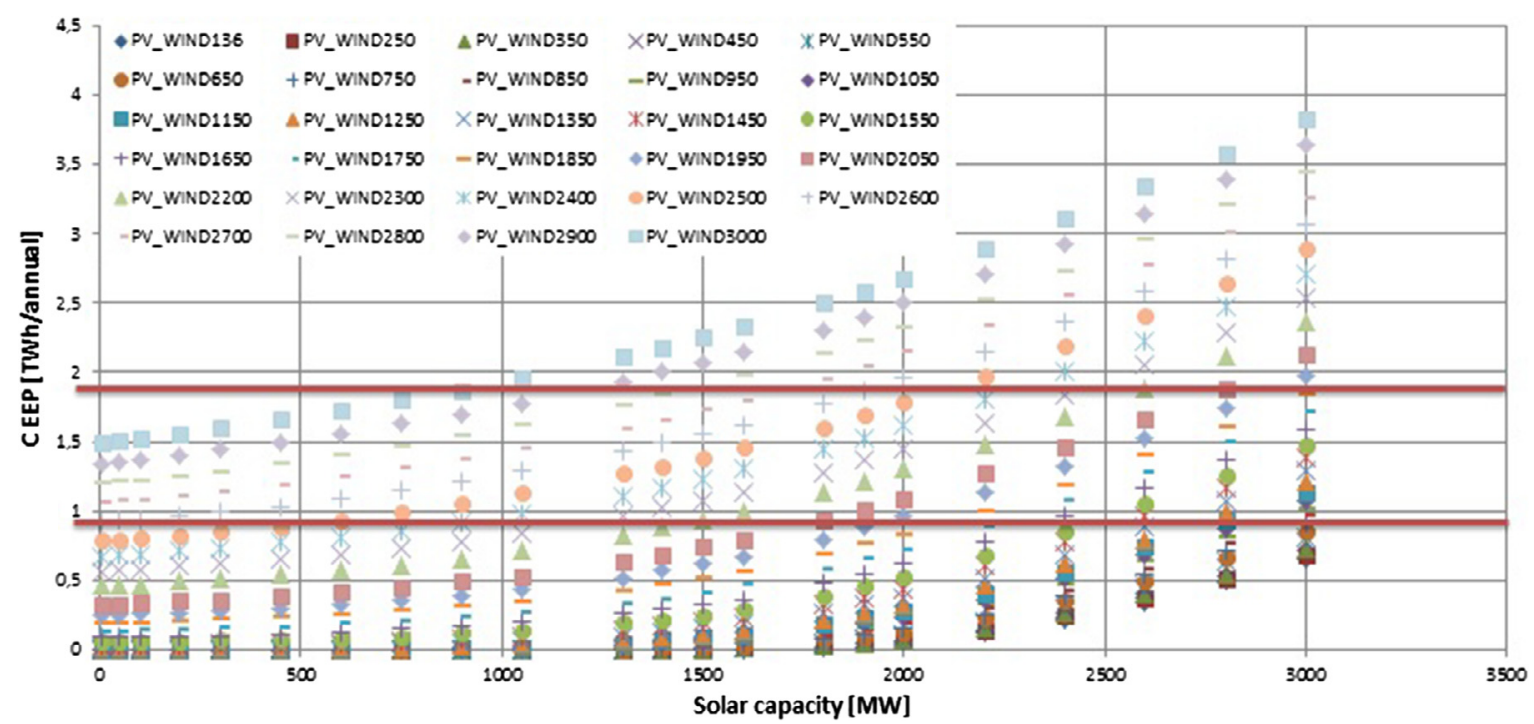

Fig. 8. CEEP-Solar PV capacity chart.

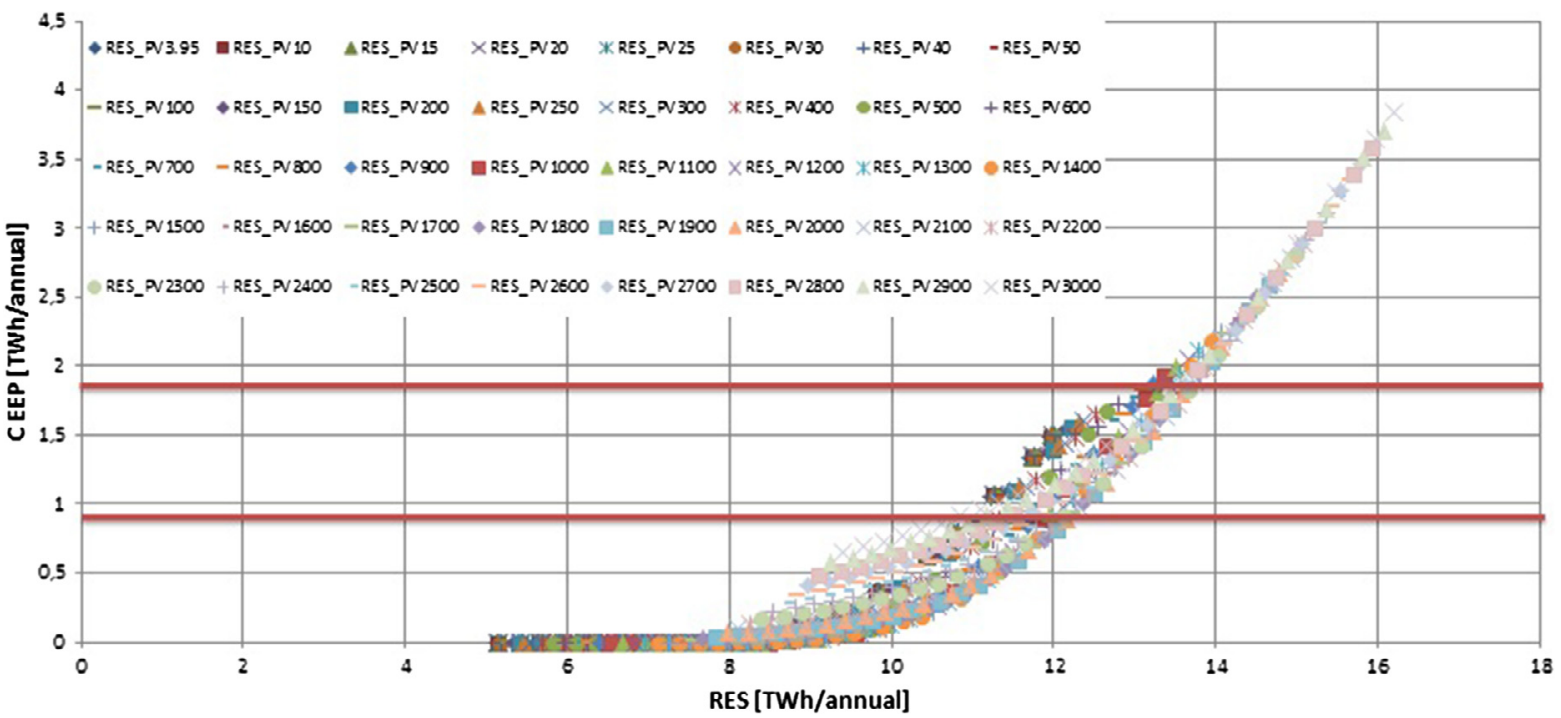

Fig. 9. CEEP-RES chart with constant PV capacity.

base technology and PV when the wind is acting as the base technology. In the case when the PV is acting as the base technology, the wind capacity was changing from $136 \mathrm{MW}$ to $1150 \mathrm{MW}$ and from $1300 \mathrm{MW}$ to $1500 \mathrm{MW}$ with a step of $100 \mathrm{MW}$ and from $1500 \mathrm{MW}$ to $2900 \mathrm{MW}$ with a step of $200 \mathrm{MW}$ and in the last case is $3000 \mathrm{MW}$. In the case when the wind is acting as the base technology, the PV capacity was changing from 3.95 MW to $100 \mathrm{MW}$ with a step of $50 \mathrm{MW}$, from $100 \mathrm{MW}$ to $300 \mathrm{MW}$ with a step of $100 \mathrm{MW}$, from $300 \mathrm{MW}$ to $1300 \mathrm{MW}$ with a step of $150 \mathrm{MW}$, from $1300 \mathrm{MW}$ to $1600 \mathrm{MW}$ and from $1800 \mathrm{MW}$ to $2000 \mathrm{MW}$ with a step of $100 \mathrm{MW}$ and from $2000 \mathrm{MW}$ to $3000 \mathrm{MW}$ with a step of $200 \mathrm{MW}$. At the end 1518 cases were created and for each case CEEP, production of RES electricity, import of electricity and $\mathrm{CO}_{2}$ emissions were calculated. Also, for each of those two major scenarios sensitivity analysis were conducted in order to find the optimal scenario for the analysed energy system.

As the scenarios would explore the increase in capacity from wind and PV power plants, electricity excess would occur after a certain point. Studying the impact of increased wind and PV capacity on CEEP should describe how much of the mentioned capacity could be installed in the power load system without risking a failure, which could result in a blackout. With the EU member states (such as Denmark and Germany) looking for a way to combine a large penetration of renewable energy, while on the other side having a low CEEP, this paper focuses a lot on the behaviour of CEEP with different combinations of installed wind and PV power. The second aspect of the energy scenarios was the amount of electricity produced from renewable energy, RES. Due to the different load factors of wind and PV power, it would be very interesting to see which scenario would offer the most "green electricity". In addition, the import of electricity is also a key topic in the EU energy sector, especially for Germany, where more and more electricity is being imported due to the fluctuations of wind and PV power plants. Therefore, the scenarios in this paper also show the behaviour of the import of electricity through various combinations of wind and PV power. Finally, with almost every country looking to reduce $\mathrm{CO}_{2}$ emissions, the installation of new wind and PV power plants would definitely help towards that, the only question is how much. Therefore, throughout this whole paper the $\mathrm{CO}_{2}$ emissions were analysed. 


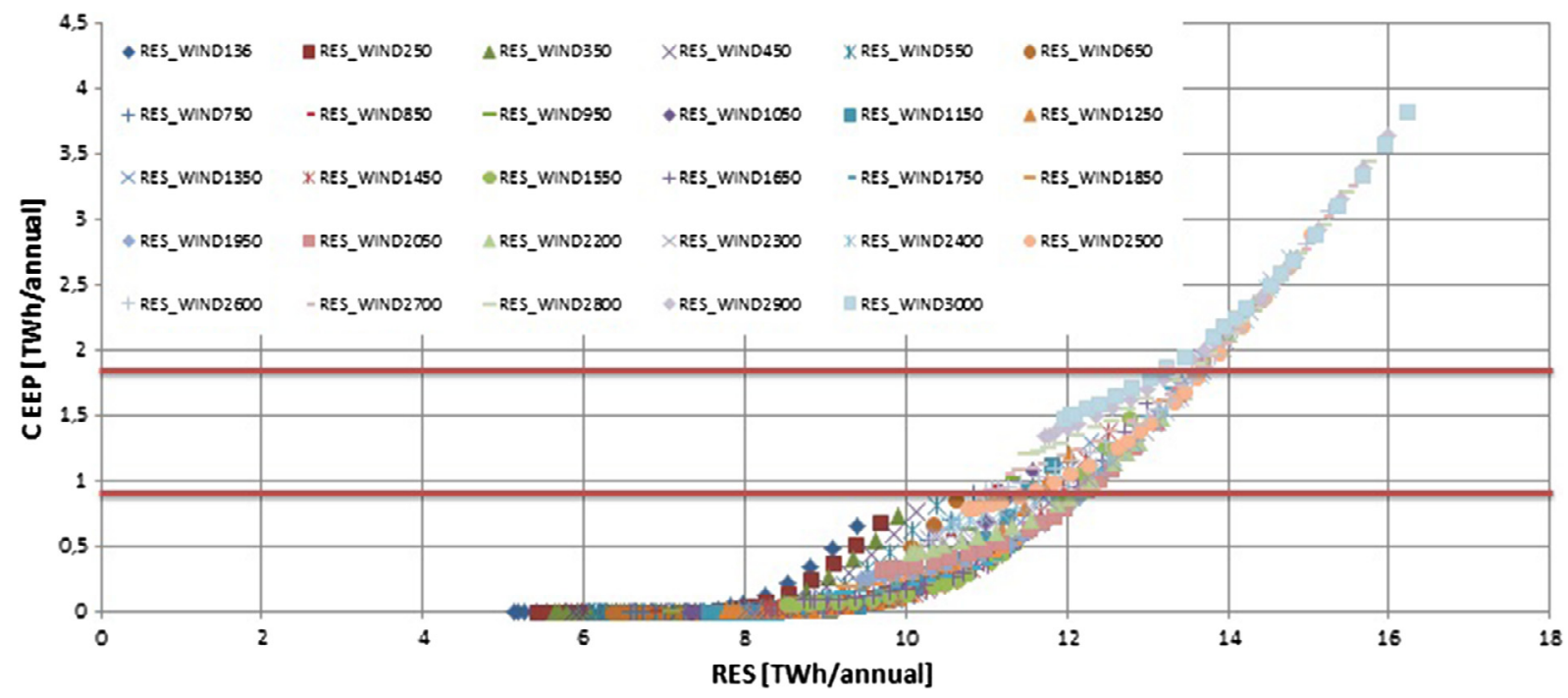

Fig. 10. CEEP-RES chart with constant wind capacity.

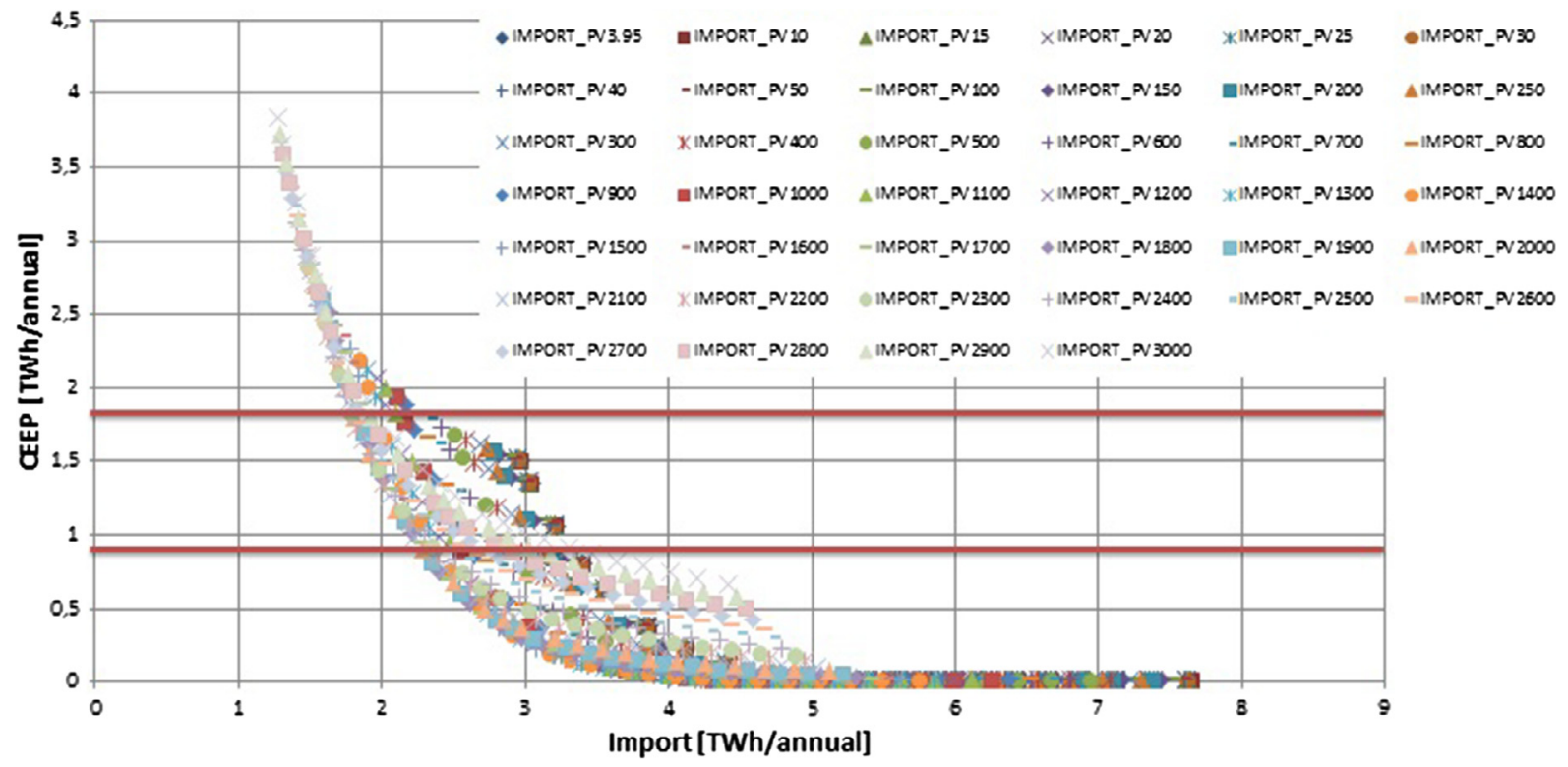

Fig. 11. CEEP-Import chart with constant PV capacity.

Many problems in engineering require optimisation. For instance, this paper requires an optimisation of the installed capacity, therefore, a selection of the optimal solutions among a set of possible alternatives is necessary. A natural scenario in the optimisation field is to have more than one objective to optimise simultaneously, which results in a conflict of these objectives with one another. In the case of multiple objective optimisation problems with several objectives to be optimised simultaneously, such as CEEP, import of electricity, $\mathrm{CO}_{2}$ emissions and share of RES, an optimal solution to this problem is the one that achieves the lowest CEEP, import of electricity and $\mathrm{CO}_{2}$ emissions and the highest share of RES. In this case, several possible solutions exist and main question here is to find which of the solutions are better. The same scenario can be seen in Fig. 2, where the red line represents all optimal solutions. This set of optimal solutions is also known as the Pareto front.

In the case of wind installation main focus in this paper is on on-shore wind power plants because of restrictive legislation in the case of off-shore wind installation, which at the moment prohibits construction of off-shore wind plants in the Adriatic Sea. In the case of PV installation main focus is on small roof PV systems which are at the moment very popular for installation with private customers because of high feed-in tariffs combined with long term contracts and relatively low investment costs for the PV systems. The geographical distribution and planned capacities of wind and PV projects in Croatia are given in the Registry of projects and plants for use of RES and CHP at the Ministry of Economy, Labour and Entrepreneurship and at the moment total capacity of wind projects in the Registry is $1.7 \mathrm{GW}$ and in the case of PV installation is $81.5 \mathrm{MW}$ [39]. The current installed capacity of wind power plants in Croatia is $743.95 \mathrm{MW}$ and $55 \mathrm{MW}$ of PV installations [40]. The main reason for the small number of PV installations is because of the limitation for the feed-in contracts set by the government. In addition, the load factor of current wind power plants in Croatia for the reference year was $26 \%$, while the levelized cost of electricity production (LCOE) is $50-85 € / \mathrm{MWh}$ and the main 
influence on LCOE have discount rate, load factor and investment costs [41]. In the case of PV systems average load factor for the reference year in the Croatia is $13 \%$, while LCOE is $75-220$ $€ / \mathrm{MWh}$ in the case of projects up to $2 \mathrm{MW}$ and $50-140 € / \mathrm{MWh}$ in the case of projects with installed capacity over $10 \mathrm{MW}$ [41].

On the other side, the Croatian import and export capacity is around $3200 \mathrm{MW}$ [20] with very good $400 \mathrm{kV}, 220 \mathrm{kV}$ and $110 \mathrm{kV}$ connections with neighbouring countries [42]. Furthermore, transmission networks of the neighbouring countries are very well developed [43] which presents a promising potential for a high integration of intermittent renewable energy sources [44].

\section{Results}

Analysis for different penetration of wind and PV and their impact on the CEEP, $\mathrm{CO}_{2}$ emissions, electricity import and RES production in the case of Croatia were conducted in 69 scenarios where PV and wind were the base technologies. In order to analyse energy system of Croatia with a high share of intermittent renewable energy sources, the technical regulation strategy has been used. The technical regulation strategy focuses on satisfying both heat and electricity demand by balancing production from available power plants in the system, while at the same time seeking to avoid or minimise CEEP. Also, all analysis was carried out for the year 2012 therefore a calculation of a new demand was not required. Data needed to create a reference scenario were collected from available database explained in detail in [20]. Furthermore, the wind distribution curve was created using measured wind speed on different locations and detailed explanation how it was calculated was given in [45].

The main criterion, CEEP, has been calculated using serial calculations due to the fact that EnergyPLAN allows obtaining values of a certain output parameter for the given scenario, such as CEEP, depending on an input, which is in this case the installed capacity of wind and $\mathrm{PV}$ power plants. In order to provide a simpler explanation of the behaviour of CEEP, Fig. 3 shows how with the increase in the input, which in this case is the wind capacity, CEEP rises almost exponentially.
The results obtained for different penetration of the wind and PV showed that both technologies have similar patterns in the case of CEEP, which can be seen in Figs. 3 and 4. The idea of achieving the optimal scenario would depend heavily on CEEP and its increase.

Although Fig. 4 seems identical to Fig. 3, there is an important difference. In Fig. 4 for a higher amount of installed wind capacity than PV capacity results in a lower CEEP. This already indicates that the optimal scenario would have more installed wind capacity than PV.

In order to perform the Pareto analysis, the results from two major scenarios were put separately in a chart as shown in Figs. 5 and 6. With the results are in a chart, the Pareto analysis is used and the results are all the cases that can be found on the black curve. Only cases with a CEEP kept below $10 \%$ of the demand (upper red line) and when CEEP is kept below $5 \%$ of the demand (lower red line) were considered. Fig. 5 shows how the scenarios were selected for the constant PV capacity.

With the increase of PV capacities the $\mathrm{CO}_{2}$ decreases, while $\mathrm{CEEP}$ increases. The optimal scenarios according to the Pareto analysis would be found in the lower left part of Fig. 5. A more detailed view can be seen in Table 1 .

Following the same principle that was used in Fig. 5, Fig. 6 shows the results for constant wind capacity. However, the results are a bit wider than in the previous chart. Fig. 6 identified several scenarios between 1650 and $2300 \mathrm{MW}$ of installed wind capacity to be optimal.

The optimal scenarios according to Fig. 6 can be found in Table 2 in a more expanded view. Table 2 shows how the scenario with the largest amount of installed capacity (both PV and wind), and therefore the largest RES, results in a lower import and lower $\mathrm{CO}_{2}$ emissions. On the other side, in the mentioned scenario CEEP raises more drastically, compared to the other scenarios.

Taking into account that the Pareto analysis was explained in detail, the curve used to show the optimal solutions will not be used in Figs. 7-12 in order to maintain a level of transparency.

To present a more detailed version of Fig. 3, Fig. 7 was introduced. It can be seen that CEEP increases with wind capacity, therefore, it doesn't come as a surprise that the Pareto analysis chose the case with the minimum installed PV capacity.

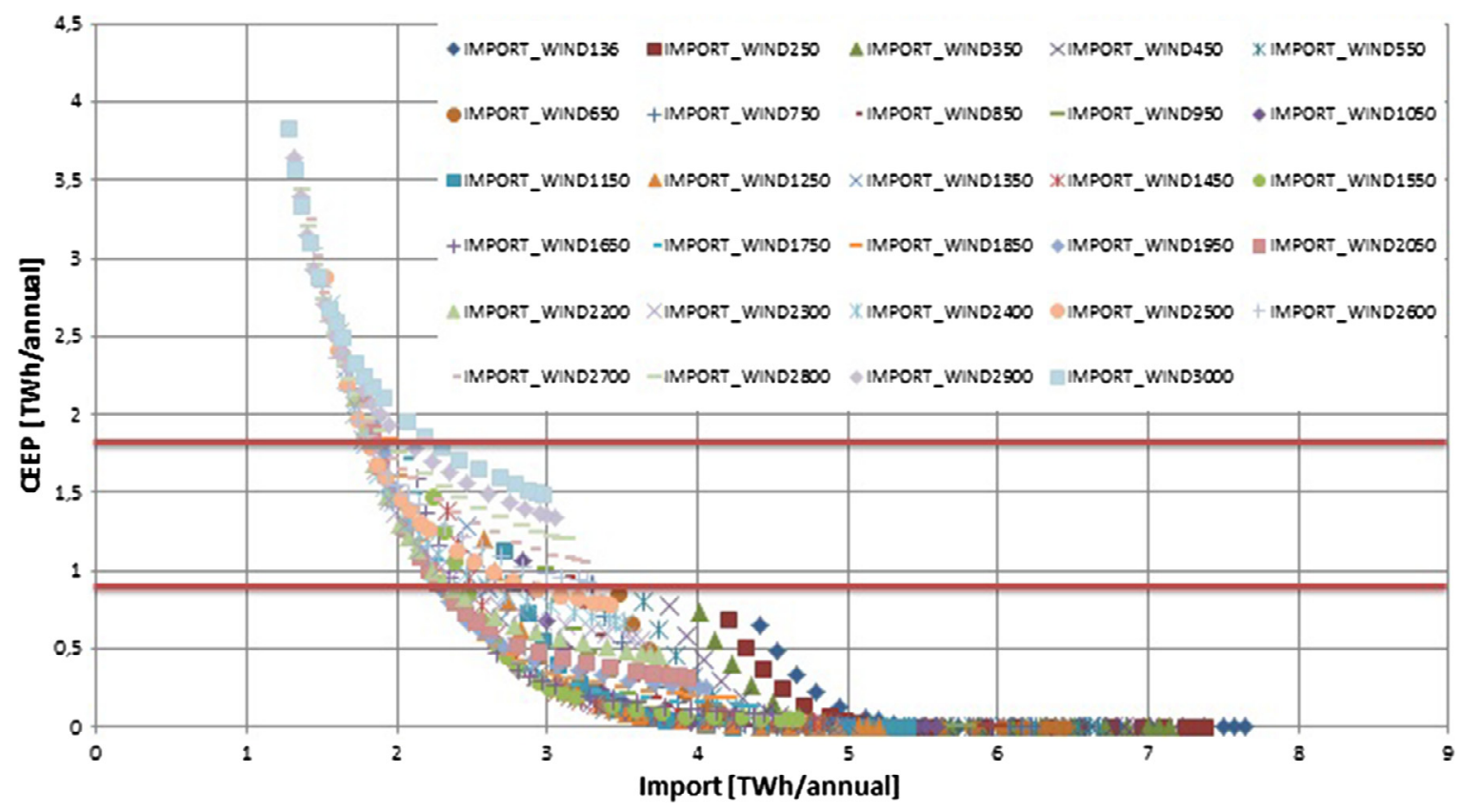

Fig. 12. CEEP-Import chart with constant wind capacity. 
The results from Fig. 7, which can be found in Table 3, suggest that all those scenarios are optimal. However, due to the fact that Fig. 7 shows the behaviour of CEEP compared to the installed wind capacity, the optimal scenarios would obviously be the points of lowest PV capacity. In addition, due to the work regime of EnergyPLAN, which is usually used for larger capacities, the CEEP curve looks the same for the cases when PV capacity is $3.95 \mathrm{MW}$ and when it is $40 \mathrm{MW}$. Due to a low impact on CEEP and RES, this paper will focus on the scenarios with $40 \mathrm{MW}$ of PV.

Repeating the same explanation as for Fig. 7, Fig. 8 had the same results. Due to an increase of CEEP the Pareto analysis identified the case with $136 \mathrm{MW}$ of installed wind capacity to be the optimal one.

In Table 4 the same principle of results, as in Table 3 , will be shown, where this time the capacity of wind will be constant. Pattern behaviour can be observed once again, this time in Table 4, where CEEP decreases together with RES, while the electricity import and $\mathrm{CO}_{2}$ emissions increase with a reduced value in PV capacity. However, after comparing the results in Tables 3 and 4 with the scenarios which had an almost equal share of wind and $\mathrm{PV}$, it can be observed that the scenarios which had the equal share have a lower CEEP and the RES, while import of electricity would be higher, for the same total amount of installed capacity.

In order to find out how does the share of renewable energy (RES) influence the decision of choosing an optimal scenario, it was put together with CEEP in a chart, as it is shown in Fig. 9.

Table 3

Optimal scenarios for the CEEP-Wind capacity chart.

\begin{tabular}{llllll}
\hline $\begin{array}{l}\text { Wind } \\
\text { capacity } \\
\text { [MW] }\end{array}$ & $\begin{array}{l}\text { PV capacity } \\
\text { [MW] }\end{array}$ & $\begin{array}{l}\mathrm{CEEP} \\
\text { [TWh/ } \\
\text { year] }\end{array}$ & $\begin{array}{l}\text { Import } \\
\text { [TWh/year] }\end{array}$ & $\begin{array}{l}\mathrm{RES} \\
{[\mathrm{TWh} /} \\
\text { year] }\end{array}$ & $\begin{array}{l}\mathrm{CO}_{2} \\
\text { emission } \\
\text { [Mt] }\end{array}$ \\
\hline 3000 & 40 & 1.5 & 2.93 & 12.01 & 16.61 \\
2900 & 40 & 1.35 & 3.01 & 11.77 & 16.62 \\
2700 & 40 & 1.06 & 3.18 & 11.29 & 16.63 \\
2500 & 40 & 0.8 & 3.37 & 10.82 & 16.64 \\
2350 & 40 & 0.13 & 3.53 & 10.46 & 16.65 \\
2100 & 40 & 0.06 & 3.82 & 9.86 & 16.67 \\
\hline
\end{tabular}

Table 4

Optimal scenarios for the CEEP-Solar PV capacity chart.

\begin{tabular}{|c|c|c|c|c|c|}
\hline $\begin{array}{l}\text { Wind } \\
\text { capacity } \\
{[\mathrm{MW}]}\end{array}$ & $\begin{array}{l}\text { PV capacity } \\
{[\mathrm{MW}]}\end{array}$ & $\begin{array}{l}\text { CEEP } \\
\text { [TWh/ } \\
\text { year] }\end{array}$ & $\begin{array}{l}\text { Import } \\
\text { [TWh/year] }\end{array}$ & $\begin{array}{l}\text { RES } \\
\text { [TWh/ } \\
\text { year] }\end{array}$ & $\begin{array}{l}\mathrm{CO}_{2} \\
\text { emission } \\
{[\mathrm{Mt}]}\end{array}$ \\
\hline 136 & 3000 & 0.65 & 4.42 & 9.39 & 16.59 \\
\hline 136 & 2800 & 0.49 & 4.53 & 9.1 & 16.68 \\
\hline 136 & 2600 & 0.34 & 4.66 & 8.82 & 16.68 \\
\hline 136 & 2400 & 0.22 & 4.79 & 8.53 & 16.69 \\
\hline 136 & 2200 & 0.13 & 4.95 & 8.25 & 16.7 \\
\hline 136 & 2000 & 0.06 & 5.12 & 7.97 & 16.73 \\
\hline
\end{tabular}

Table 5

Optimal scenarios for the CEEP-RES chart when the PV capacity is constant.

\begin{tabular}{|c|c|c|c|c|c|}
\hline $\begin{array}{l}\text { Wind } \\
\text { capacity } \\
{[\mathrm{MW}]}\end{array}$ & $\begin{array}{l}\text { PV capacity } \\
{[\mathrm{MW}]}\end{array}$ & $\begin{array}{l}\text { CEEP } \\
\text { [TWh/ } \\
\text { year] }\end{array}$ & $\begin{array}{l}\text { Import } \\
\text { [TWh/year] }\end{array}$ & $\begin{array}{l}\text { RES } \\
\text { [TWh/ } \\
\text { year] }\end{array}$ & $\begin{array}{l}\mathrm{CO}_{2} \\
\text { emission } \\
\text { [Mt] }\end{array}$ \\
\hline 2350 & 2100 & 1.63 & 1.86 & 13.39 & 16.49 \\
\hline 1700 & 2100 & 0.75 & 2.44 & 11.84 & 16.52 \\
\hline 1900 & 2000 & 0.89 & 2.29 & 12.17 & 16.51 \\
\hline 1500 & 1900 & 0.59 & 2.55 & 11.55 & 16.52 \\
\hline 1500 & 2100 & 0.56 & 2.67 & 11.36 & 16.55 \\
\hline 2350 & 1900 & 1.45 & 1.96 & 13.1 & 16.49 \\
\hline
\end{tabular}

Larger amount of installed capacity had of course the effect of increased CEEP and the increase of RES. Therefore, the results showed that the optimal scenarios include a set value of installed PV capacity between 1900 and 2100 MW. The optimal scenarios according to Fig. 9 can be found in Table 5 in a more expanded view.

Corresponding to Fig. 9, Fig. 10 shows the same solution only with constant installed wind capacity. The results again presented a wider variety of scenarios, from $1450 \mathrm{MW}$ to $2500 \mathrm{MW}$ of installed wind capacity to be optimal.

Fig. 10 shows how the increase in installed capacity would result with a higher RES, however, RES should not be the highest possible. Due to the fact that CEEP also increases with the increase in installed capacity, the Pareto analysis of this scenario would be extremely useful. The optimal scenarios according to Fig. 10 would be on the lower right part of the chart and they can be found in Table 6 in a more expanded view.

With the import of electricity being a big reason for writing this paper, it was also included in a chart to find the optimal scenarios. For a constant value of installed PV capacity the results showed that the requirements fulfil scenarios from 1400 to $2200 \mathrm{MW}$ of installed PV capacity.

It was previously shown how the increase of installed capacity increases CEEP, however, this time it is more important to see how the import decreases with the increase in installed capacity. Optimal scenarios from Fig. 11 would be in the lower left part of the chart, which can be seen in Table 7 .

Table 6

Optimal scenarios for the CEEP-RES chart when the wind capacity is constant.

\begin{tabular}{llllll}
\hline $\begin{array}{l}\text { Wind } \\
\text { capacity } \\
\text { [MW] }\end{array}$ & $\begin{array}{l}\text { PV capacity } \\
{[\mathrm{MW}]}\end{array}$ & $\begin{array}{l}\mathrm{CEEP} \\
\text { [TWh/ } \\
\text { year] }\end{array}$ & $\begin{array}{l}\text { Import } \\
\text { [TWh/year] }\end{array}$ & $\begin{array}{l}\mathrm{RES} \\
{[\mathrm{TWh} /} \\
\text { year] }\end{array}$ & $\begin{array}{l}\mathrm{CO}_{2} \\
\text { emission } \\
\text { [Mt] }\end{array}$ \\
\hline 1450 & 1400 & 0.17 & 3.23 & 10.25 & 16.63 \\
1550 & 1400 & 0.22 & 3.09 & 10.48 & 16.6 \\
1650 & 1400 & 0.29 & 2.96 & 10.72 & 16.59 \\
1650 & 1600 & 0.36 & 2.81 & 11.01 & 16.55 \\
1750 & 1600 & 0.46 & 2.69 & 11.24 & 16.54 \\
2050 & 1600 & 0.8 & 2.38 & 11.96 & 16.52 \\
2300 & 1800 & 1.28 & 2.04 & 12.84 & 16.5 \\
2400 & 1900 & 1.53 & 1.92 & 13.22 & 16.49 \\
\hline
\end{tabular}

Table 7

Optimal scenarios for the CEEP-Import chart when the PV capacity is constant.

\begin{tabular}{|c|c|c|c|c|c|}
\hline $\begin{array}{l}\text { Wind } \\
\text { capacity } \\
{[\mathrm{MW}]}\end{array}$ & $\begin{array}{l}\text { PV capacity } \\
\text { [MW] }\end{array}$ & $\begin{array}{l}\text { CEEP } \\
\text { [TWh/ } \\
\text { year] }\end{array}$ & $\begin{array}{l}\text { Import } \\
\text { [TWh/year] }\end{array}$ & $\begin{array}{l}\text { RES } \\
{[\text { TWh/ }} \\
\text { year] }\end{array}$ & $\begin{array}{l}\mathrm{CO}_{2} \\
\text { emission } \\
{[\mathrm{Mt}]}\end{array}$ \\
\hline 1400 & 1400 & 0.15 & 3.3 & 10.13 & 16.64 \\
\hline 1500 & 1500 & 0.22 & 3.08 & 10.51 & 16.6 \\
\hline 1700 & 1800 & 0.53 & 2.62 & 11.41 & 16.53 \\
\hline 1700 & 2000 & 0.67 & 2.5 & 11.69 & 16.52 \\
\hline 2350 & 2200 & 1.72 & 1.82 & 13.53 & 16.5 \\
\hline
\end{tabular}

Table 8

Optimal scenarios for the CEEP-Import chart when the wind capacity is constant.

\begin{tabular}{|c|c|c|c|c|c|}
\hline $\begin{array}{l}\text { Wind } \\
\text { capacity } \\
\text { [MW] }\end{array}$ & $\begin{array}{l}\text { PV capacity } \\
{[\mathrm{MW}]}\end{array}$ & $\begin{array}{l}\text { CEEP } \\
{[\mathrm{TWh} /} \\
\text { year] }\end{array}$ & $\begin{array}{l}\text { Import } \\
\text { [TWh/year] }\end{array}$ & $\begin{array}{l}\text { RES } \\
\text { [TWh/ } \\
\text { year] }\end{array}$ & $\begin{array}{l}\mathrm{CO}_{2} \\
\text { emission } \\
{[\mathrm{Mt}]}\end{array}$ \\
\hline 1550 & 1400 & 0.22 & 3.09 & 10.48 & 16.6 \\
\hline 1650 & 1400 & 0.29 & 2.96 & 10.72 & 16.59 \\
\hline 2050 & 1600 & 0.8 & 2.38 & 11.96 & 16.52 \\
\hline 2300 & 1800 & 1.28 & 2.04 & 12.84 & 16.5 \\
\hline 2400 & 1800 & 1.44 & 1.98 & 13.08 & 16.49 \\
\hline
\end{tabular}


Afterwards, following the same principle from Fig. 11, in Fig. 12 CEEP would increase and the import would decrease, as the installed capacity rises. In this Pareto analysis, where installed wind capacity is constant, the optimal scenarios would have a size of the installed wind capacity between 1550 and $2400 \mathrm{MW}$.

The Pareto analysis in Fig. 12 presents the optimal scenarios with installed PV capacity between 1400 and $1800 \mathrm{MW}$, which is very similar to the optimal scenarios from the previous case. A more detailed view of the optimal scenarios can be seen in Table 8 .

\subsection{Scenario rating}

Due to the fact that now the scenarios are limited to 39 of them, in order to reduce them even further, multiple criteria decisions were used. Multiple criteria decision analysis (MCDA) is a method used to make a decision on several scenarios based on their value and weight [46]. Although today there are several MCDA methods available, in this paper the multi-attribute value theory (MAVT) was used. In this approach, after a series of decision criteria have been selected, the scenarios were graded on an appropriate scale. Each criterion was given their weight and partial value that represents the criteria in the overall score. Due to the fact that the most important factor for a country is grid stability, CEEP was accredited with the highest assigned weight. On the other side, due to a high share of imported electricity, it was expected that the $\mathrm{CO}_{2}$ emissions would not change significantly, therefore, it was assigned with the lowest weight. In addition, RES and import of electricity were assigned the same weight because their effect was more important than $\mathrm{CO}_{2}$ emission but not as much as CEEP. Regarding the criteria values, the values in the category worst were the data from the reference year, while the values from the category best were gained from the results of 39 scenarios, indicating the best possible values overall. Finally, the overall score was calculated and final scenario was given. All of the above can be seen more detailed in Table 9. Due to the fact that the Pareto analysis shows optimal scenarios, they did not diverge a lot in the MAVT.

The mathematical formulation is the following:

$V(a)=\sum_{j-1}^{n} w_{j}\left[v_{j}(a)\right]$

where $v_{j}\left(\right.$ best $\left._{j}\right)=100, v_{j}\left(\right.$ worst $\left._{j}\right)=0, V($ best overall $)=100, V($ worst overall $)=0, v_{j}=\left(\right.$ value $_{j}$-worst $) /($ best-worst $)$, is the normalisation, $w_{j}$ is the scaling constant, $v_{j}(a)$ is the partial value (score) of option a in terms of criterion $j, V(a)$, is the overall value (score) of option a.

All of those scenarios were computed with the MAVT and in Table 10 two detailed computations can be seen. Those scenarios were the worst ones offered by the Pareto analysis.

As it can be seen in Table 10, the selected scenarios did show a possible solution, but due to their relatively high CEEP they were found to be the worst scenarios. However, Table 11 shows scenarios which were chosen as optimal and after the MAVT confirmed their role as suitable scenarios for the power load system of Croatia. Although the scenario with less wind had better overall weight, the second one, with $100 \mathrm{MW}$ more wind power had its own pros and cons. The advantage would be generating more jobs, which is considered one of the priorities for Croatia's economy, while the disadvantage would be a higher capital cost together with a larger CEEP.

\subsection{Sensitivity analysis}

After the previous chapter showed which scenario was optimal according to the MAVT, this chapter focuses on the analysis of the assigned weight of each criterion. This sensitivity analysis was carried out in a way where two of the criterions would remain
Table 9

Decision criteria value ranges and assigned weight.

\begin{tabular}{llll}
\hline \multirow{2}{*}{ Optimisation criteria } & \multicolumn{2}{l}{ Criteria values } & \multirow{2}{*}{ Assigned weight \% } \\
\cline { 2 - 3 } & Best & Worst & \\
\hline CEEP (TWh/annual) & 0 & 1.82 & 30 \\
RES (TWh/annual) & 17 & 5 & 25 \\
Import (TWh/annual) & 0 & 8 & 25 \\
$\mathrm{CO}_{2}$ emission [Mt] & 16.47 & 17 & 20 \\
\hline
\end{tabular}

Table 10

The overall score for the worst selected scenarios.

\begin{tabular}{|c|c|c|c|c|c|c|}
\hline & $\begin{array}{l}1.9 \mathrm{GW} \\
\text { PV } \\
\text { Value }\end{array}$ & $\begin{array}{l}2.4 \mathrm{GW} \\
\text { Wind } \\
\text { Norm }\end{array}$ & Weight & $\begin{array}{l}1.8 \mathrm{GW} \\
\text { PV } \\
\text { Value }\end{array}$ & $\begin{array}{l}2.3 \mathrm{GW} \\
\text { Wind } \\
\text { Norm }\end{array}$ & Weight \\
\hline CEEP & 1.53 & 15.93 & 4.78 & 1.28 & 29.67 & 8.9 \\
\hline RES & 13.22 & 68.5 & 17.13 & 12.84 & 65.33 & 16.33 \\
\hline Import & 1.92 & 76 & 19 & 2.04 & 74.5 & 18.63 \\
\hline $\mathrm{CO}_{2}$ & 16.49 & 96.23 & 19.25 & 16.5 & 94.34 & 18.87 \\
\hline Overall & & & 60.15 & & & 62.73 \\
\hline
\end{tabular}

Table 11

The overall score for the best selected scenarios.

\begin{tabular}{lllllll}
\hline & $\begin{array}{l}1.6 \mathrm{GW} \\
\mathrm{PV} \\
\text { Value }\end{array}$ & $\begin{array}{l}1.65 \mathrm{GW} \\
\text { Wind } \\
\text { Norm }\end{array}$ & Weight & $\begin{array}{l}\text { 1.6 GW } \\
\text { PV }\end{array}$ & $\begin{array}{l}1.75 \mathrm{GW} \\
\text { Wind } \\
\text { Vorm }\end{array}$ & Weight \\
\hline CEEP & 0.36 & 80.22 & 24.07 & 0.46 & 74.73 & 22.42 \\
RES & 11.01 & 50.08 & 12.52 & 11.24 & 52 & 13 \\
Import & 2.81 & 64.88 & 16.22 & 2.69 & 66.38 & 16.59 \\
$\mathrm{CO}_{2}$ & 16.55 & 84.91 & 16.98 & 16.54 & 86.79 & 17.36 \\
Overall & & & 69.79 & & & 69.37 \\
\hline
\end{tabular}

constant, while the other two would change their values. One of the two variable criterions would have its value increased by $10 \%, 20 \%, 30 \%, 40 \%$ and $50 \%$, while the second criterion would have its value reduced proportionally. Following that, the two variable criterions would just switch their roles.

The first example included the sensitivity analysis where the weight of import and $\mathrm{CO}_{2}$ emissions remained constant, while CEEP and RES changed their values, which can be observed in Fig. 13. When the weight of CEEP was reduced, the weight of RES would increase. In that case, the overall score for all scenarios would be reduced. However, the biggest impact of that change could be seen on scenarios which had the lowest amount of installed capacity of renewables, which of course means the lowest RES.

In addition, Fig. 13 shows how with the increase of CEEP weight the overall score of all scenarios improved, which benefited the best overall scenario due to the fact that it had the lowest CEEP and the lowest RES.

Following the same principle from the previous example, Fig. 14 differs because this time RES and import of electricity were constant criterions, where the weight of CEEP and $\mathrm{CO}_{2}$ emissions was changing. With the increase of $\mathrm{CO}_{2}$ weight factor, the CEEP weight factor was reduced, which had a result of the increase of the overall score for all scenarios. That benefited the scenarios with the largest amount of installed amount of renewables, because it would contribute to a larger $\mathrm{CO}_{2}$ reduction than the other scenarios.

Fig. 14 also shows how the increase of the CEEP weight would benefit the scenarios with the lowest CEEP. 


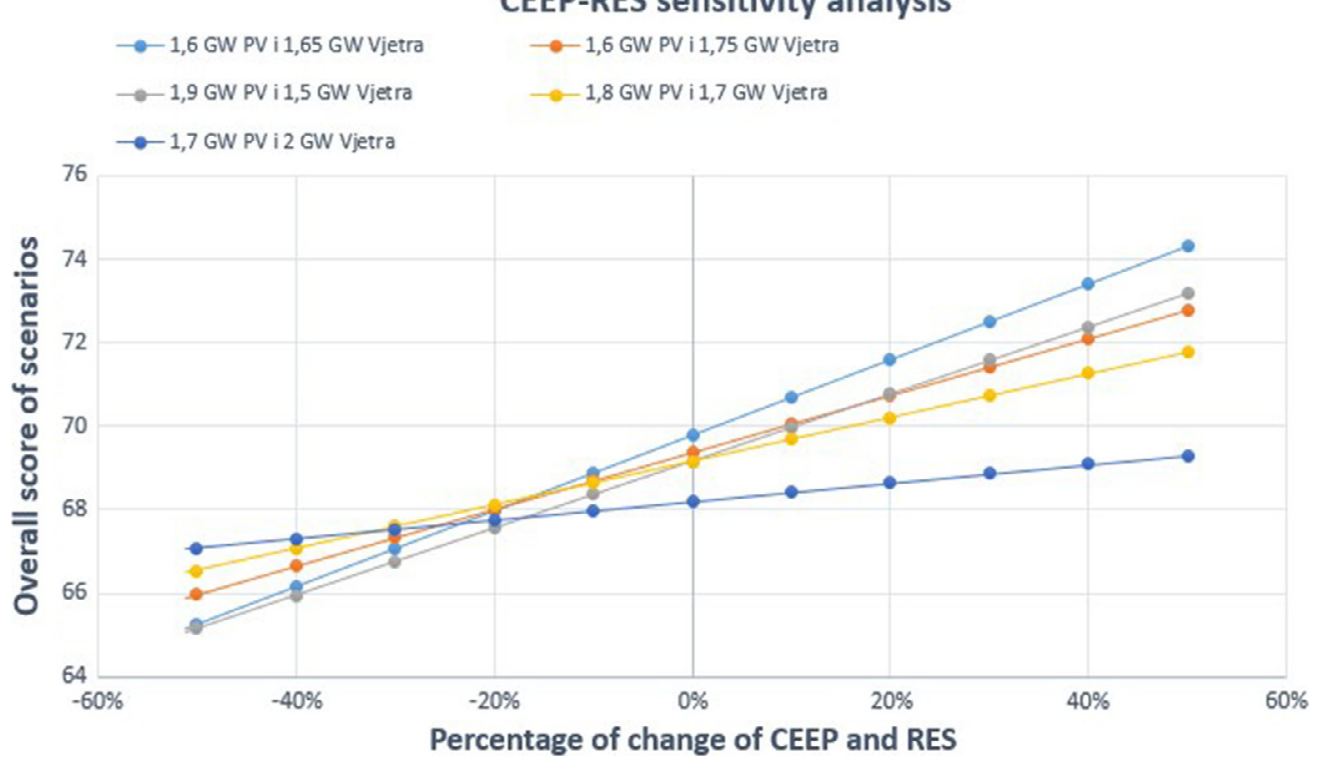

Fig. 13. CEEP-RES chart for a change in the weight factor.

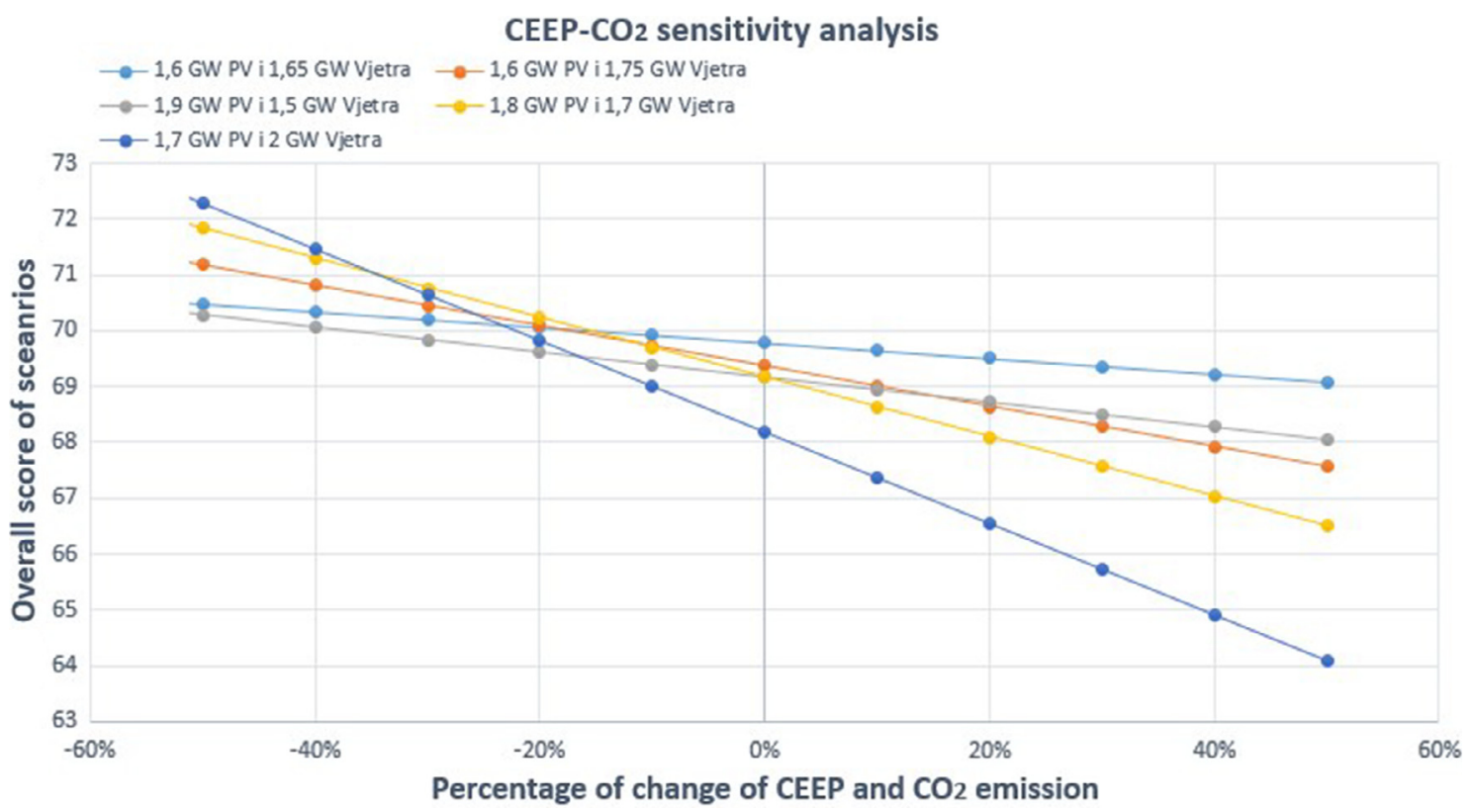

Fig. 14. $\mathrm{CEEP}-\mathrm{CO}_{2}$ chart for a change in the weight factor.

As the last example of the sensitivity analysis, Fig. 15 shows the case when $\mathrm{CO}_{2}$ and RES weights were constant while CEEP and import of electricity were changing their weight factors. As it was previously shown, the increase of CEEP weight would benefit the best overall scenarios due to the fact that it was the scenario with the lowest CEEP. On the other hand, reducing the weight of CEEP would help the scenarios with the largest amount of installed renewable capacity because those scenarios would reduce the import the most.

The previous three charts showed that a $10 \%$ decrease of the CEEP weight factor would not change the fact that the scenario with $1.65 \mathrm{GW}$ of wind and $1.6 \mathrm{GW}$ of PV was the best overall scenario. However, a 20\% decrease of CEEP would not make it the best overall scenario. On the other side, when the weight factor of CEEP increased, the overall score increased for most of the scenarios in the CEEP-RES and CEEP-Import chart, but the difference in the score between the best overall scenario and other scenarios increased linearly. Finally, the $\mathrm{CEEP}-\mathrm{CO}_{2}$ chart had a similar behaviour, the increase of the CEEP weight factor would make a bigger difference between the scores, while the overall scores were decreasing. In addition, a decrease in the CEEP weight factor would increase the overall score of all scenarios and as the weight factor was reduced so was the ranking of the best overall scenario. 


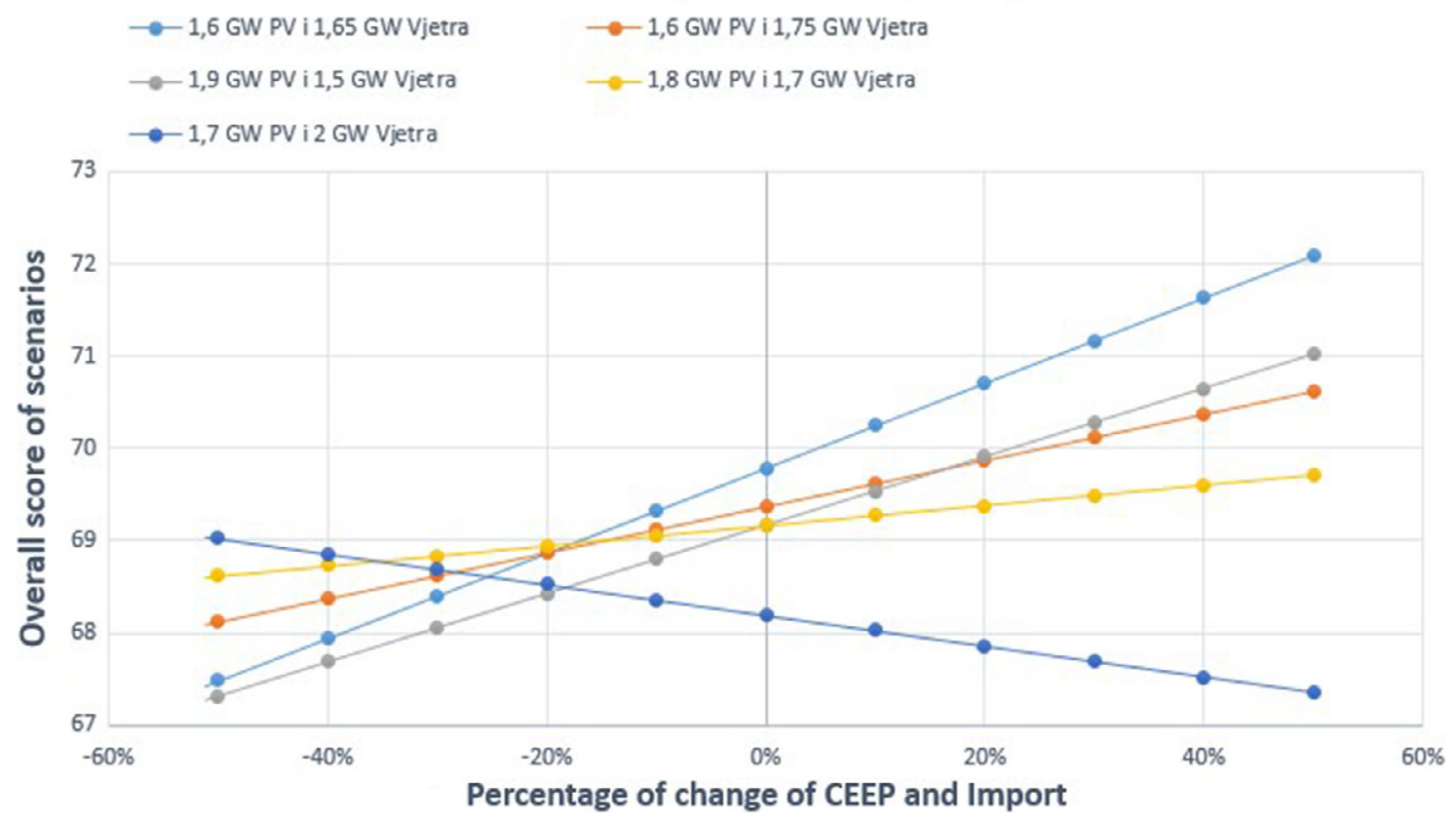

CEEP-Import sensitivity analysis

$-1,6 \mathrm{GW}$ PV i $1,75 \mathrm{GW}$ Vjetra

$-1,8 \mathrm{GW}$ PV i $1,7 \mathrm{GW}$ Vjetra

Fig. 15. CEEP-Import chart for a change in the weight factor.

\section{Conclusion}

A general direction for the new Croatian energy strategy has been presented. Taking into account that the Republic of Croatia imports a significant amount of electricity, 36\% of its demand in 2012 to be precise, it was expected that the Croatian power load system would be able to receive a large capacity of both wind and PV power plants. The additional capacity of $1.6 \mathrm{GW}$ of wind power and $1.6 \mathrm{GW}$ of $\mathrm{PV}$ has a relatively low impact on $\mathrm{CO}_{2}$ reduction, only 300 tons annually on the national level. In addition, the impact of the above mentioned scenario could be seen in the RES category, which showed that the electricity production from renewable energy could reach $70 \%$ with this scenario.

Although usually wind power plants prevail over PV in the energy mix, that is the case for the countries of central and north Europe. Due to Croatia's geographic position, the southern parts don't have significant problems with harvesting solar energy. Therefore, PV would have a more significant role than expected. That of course should not mean that the Republic of Croatia should now only focus on PV. This paper has shown how the combination of both wind and PV power could have the impact of larger RES, rather than focusing only on one technology. In addition, the combination of wind and PV power had the effect of a lower CEEP due to the fact that the wind is more frequent during the night, which balances the PV power which is only available during the day, when the highest electricity consumption occurs.

Overall, this paper identified the scenario of $1.65 \mathrm{GW}$ of wind power and 1.6 GW of PV as the optimal scenario for the current infrastructure, which was not designed for the fast and large storage of electricity. Therefore, even though the scenario which was rated as the worst scenario that entered the multi-criteria analysis, the scenario which had installed $2.4 \mathrm{GW}$ of wind power and $1.9 \mathrm{GW}$ of PV, that scenario could be a direction for the year 2050. By the year $2050 \mathrm{CO}_{2}$ emissions should be cut down between $80 \%$ and $95 \%$ compared to the 1990 level, which would require a higher share of renewable energy in the power load system.

Regarding the assigned weight for the four criterions, the sensitivity analysis showed that a small change in the weights would not change the best overall scenario. Only a significant reduction in the CEEP weight would result that the scenarios with a larger amount of installed capacity would be optimal. On the other hand, the increase in the CEEP weight would only benefit more the already best overall scenario.

In conclusion, this technologically possible direction, which differs from the current Croatian renewable energy directions, has shown that the Republic of Croatia should not just focus on wind energy. On one side, Croatia is limiting the amount of installed PV, while on the other side this paper has shown that the increased PV capacity would result in a lower CEEP. That is mainly due to the fact that PV harvests energy during the day, when there is the largest peak of the power load system.

\section{Acknowledgment}

This work has been financially supported by the MED Programme under grant No. 1M-MED14-05 (ENERCOAST). This support is gratefully acknowledged.

\section{References}

[1] European Commission. EU energy in figures - statistical pocketbook 2014. Luxembourg: EU; 2014, ISBN 978-92-79-29317-7.

[2] European Commission policy framework for climate and energy in the period from 2020 to $2030 / \mathrm{COM} / 2014 / 015$ final/.

[3] Zervos A, Lins C, Muth J, Smith E. RE-thinking 2050: a 100\% renewable energy vision for the European Union. EREC - European Renewable Energy Council; 2010.

[4] Østergaard PA. Reviewing EnergyPLAN simulations and performance indicator applications in EnergyPLAN simulations. Appl Energy 2015;154:921-33.

[5] Szklo AS, Schaeffer R, Schuller ME, Chandler W. Brazilian energy policies side effects on $\mathrm{CO}_{2}$ emissions reduction. Energy Policy 2005;33(3):349-64.

[6] Chua KJ, Yang WM, Er SS, Ho CA. Sustainable energy systems for a remote island community. Appl Energy 2014;113:1752-63.

[7] Østergaard PA, Lund H. A renewable energy system in Frederikshavn using low-temperature geothermal energy for district heating. Appl Energy 2011;88 (2):479-87.

[8] Wenjia C, Can W, Ke W, Ying Z, Jining C. Scenario analysis on $\mathrm{CO}_{2}$ emissions reduction potential in China's electricity sector. Energy Policy 2007;35 (12):6445-56.

[9] Hickman R, Banister D. Looking over the horizon: transport and reduced $\mathrm{CO}_{2}$ emissions in the UK by 2030. Transp Policy 2007;14(5):377-87. 
[10] Shimoda Y, Yamaguchi Y, Okamura T, Taniguchi A, Yamaguchi Y. Prediction of greenhouse gas reduction potential in Japanese residential sector by residential energy end-use model. Appl Energy 2010;87(6):1944-52.

[11] Pukšec T, Duić Neven, Mathiesen BV. Potentials for energy savings and long term energy demand of Croatian households sector. Appl Energy 2013;101:15-25.

[12] Liu W, Hu W, Lund $\mathrm{H}$, Chen Z. Electric vehicles and large-scale integration of wind power - the case of Inner Mongolia in China. Appl Energy 2013:104:445-56.

[13] Mathiesen BV, Lund H, Connolly D, Wenzel H, Østergaard PA, Möller B, et al. Smart Energy Systems for coherent 100\% renewable energy and transport solutions. Appl Energy 2015;145:139-54.

[14] Krajačić G, Duić N, Zmijarević Z, Mathiesen BV, Anić-Vučinić A, Carvalho MG. Planning for a $100 \%$ independent energy system based on smart energy storage for integration of renewables and $\mathrm{CO}_{2}$ emissions reduction. Appl Therm Eng 2011;31(13):2073-83.

[15] Irsag B, Pukšec T, Duić N. Long term energy demand projection and potential for energy savings of Croatian tourism-catering trade sector. Energy 2012;48 (1):398-405.

[16] The Danish Government. Energy strategy 2050 - from coal, oil and gas to green energy; 2011.

[17] German Federal Ministry of Economics and Technology. Germany's new energy policy - heading towards 2050 with secure, affordable and environmentally sound energy; 2012.

[18] Strategy for Renewable Energy: 2012-2020 [Internet]. Irish Department of Communications, Energy and Natural Resources, Ireland; 2012. <www. dcenr.gov.ie/NR/rdonlyres/9472D68A-40F4-41B8-B8FD-F5F788D4207A/0/ RenewableEnergyStrategy2012_2020.pdf> [accessed 13.05.15].

[19] The European Wind Energy Association. Wind in power: 2011 European statistics; February 2013.

[20] Cerovac T, Ćosić B, Pukšec T, Duić N. Wind energy integration into future energy systems based on conventional plants - the case study of Croatia. Appl Energy 2014;135:643-55.

[21] International Energy Agency. Snapshot of global PV markets; 2014. ISBN 9783-906042-32-9.

[22] Ministry of Economy Labour and Entrepreneurship. Energy in Croatia - annual energy report - 2009. Zagreb, Croatia; 2010.

[23] Schmidt J, Cancella R, Pereira Jr AO. An optimal mix of solar PV, wind and hydro power for a low-carbon electricity supply in Brazil. Renew Energy 2016;85:137-47.

[24] Huber M, Weissbart C. On the optimal mix of wind and solar generation in the future Chinese power system. Energy 2015;90(part 1):235-43.

[25] Becker S, Frew BA, Andresen GB, Zeyer T, Schramm S, Greiner M, et al. Features of a fully renewable US electricity system: optimizes mixes of wind and solar PV and transmission grid extension. Energy 2014;72:443-58.

[26] Yan R, Saha TK, Modi N, Masood N, Mosadeghy M. The combined effect of high penetration of wind and PV on power system frequency response. Appl Energy 2015:145:320-30.

[27] Mills AD, Wiser RH. Strategies to mitigate declines in the economic value of wind and solar at high penetration in California. Appl Energy 2015;147:269-78.
[28] EnergyPLAN: advanced energy system analysis computer model. Aalborg University, Denmark. <www.energy.plan.aau.dk> (version 9.0).

[29] Lund H, Duić N, Krajačić G, Carvalho MG. Two energy system analysis models: a comparison of methodologies and results. Energy 2007;32(6):948-54.

[30] Connolly D, Lund $H$, Mathiesen BV, Leahy M. A review of computer tools for analysing the integration of renewable energy into various energy systems. Appl Energy 2010;87(4):1059-82.

[31] Lund H, Mathiesen BV. Energy system analysis of 100\% renewable energy systems-the case of Denmark in years 2030 and 2050. Energy 2009;34 (5):524-31.

[32] Connolly D, Lund H, Mathiesen BV, Leahy M. The first step towards a $100 \%$ renewable energy-system for Ireland. Appl Energy 2011;88(2):502-7.

[33] Ćosić B, Krajačić G, Duić N. A 100\% renewable energy system in the year 2050: the case of Macedonia. Energy 2012;48(1):80-7.

[34] Vidal-Amaro JJ, Østergaard PA, Sheinbaum-Pardo Claudia. Optimal energy mix for transitioning from fossil fuels to renewable energy sources - the case of the Mexican electricity system. Appl Energy 2015;150:80-96.

[35] Lixuan H, Henrik L, Bernd M. The importance of flexible power plant operation for Jiangsu's wind integration. Energy 2012;41(1):499-507.

[36] Le Ngoc Anh, Bhattacharyya SC. Integration of wind power into the British system in 2020. Energy 2011;36(10):5975-83.

37] Lund H. EnergyPLAN - advanced energy system analysis computer model, users manual documentation version 9.0. Aalborg, Denmark: Aalborg University; 2011.

[38] Pareto efficiency. <en.wikipedia.org/wiki/Pareto_efficiency> [accessed 13.05.16].

[39] Registry of renewable energy sources, cogeneration and feed-in production plants and projects - OIEKPP [Internet]. Ministry of Economy, Croatia; 2016. <oie-aplikacije.mingo.hr/InteraktivnaKarta/> [accessed 13.05.16].

[40] Croatian Energy Market Operator. <www.hrote.hr/default.aspx?id=135> [accessed 13.05.16].

[41] Goić R. Obnovljivi izvori energije u Hrvatskoj - danas i sutra. Energy Investment Forum 2016. Zagreb, Croatia. <www.poslovni.hr/media/article upload/files/63/63c4d649deca751cfa02b6166936881c.pptx> [accessed 13.05.16].

[42] Croatian Transmission System Operator. <www.hops.hr/wps/portal/hr/web/ hees/podaci/shema> [accessed 13.05.16].

[43] Entsoe-E. <www.entsoe.eu/map/Pages/default.aspx> [accessed 13.05.16].

[44] Dominković DF, Bačeković I, Ćosić B, Krajačić G, Pukšec T, Duić N, et al. Zero carbon energy system of South East Europe in 2050. Appl Energy 2016;184:1517-28.

[45] Krajačić G. The role of energy storage in planning of $100 \%$ renewable energy systems. PhD thesis, University of Zagreb, Faculty of Mechanical Engineering and Naval Architecture, Zagreb; 2012. <powerlab.fsb.hr/neven/pdf/supervision_of_phd_thesis/Krajacic_PHD_Energy\%20storage_100_percent_RES.pdf> [accessed 13.05.16].

[46] Løken E. Use of multicriteria decision analysis methods for energy planning problems. Renew Sust Energy Rev 2007;11(7):1584-95. 